\title{
ОБЪЕКТИВНАЯ СТОРОНА ТЕРРОРИСТИЧЕСКОГО АКТА: ТОЛКОВАНИЕ, КВАЛИФИКАЦИЯ, СОВЕРШЕНСТВОВАНИЕ
}

\begin{abstract}
Аннотация: В статье исследуется проблема объективной стороны террористического акта, подвергаются анализу и обобщаются мнения ряда ученых, проводится сравнительное уголовно-правовое исследование данного вопроса в УК государств -участников СНГ. Автор обосновывает необходимость совершенствования законодательной конструкции объективной стороны террористического акта в ст. 205 УК РФ. На основе примеров из правоприменительной практики делается вывод о том, что объективная сторона играет важную роль при квалификации террористического акта и его отграничении от иных смежных с ним преступлений.
\end{abstract}

Ключевые слова: Юриспруденция, безопасность, терроризм, террористический, объективная, толкование, квалификачия, совершенствование, отграничение, угроза

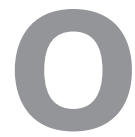

бъективная сторона, являясь обязательным элементом состава преступления, представляет собой совокупность признаков, характеризующих внешнюю сторону преступления, то есть ту ее часть, которая проявляется в объективной реальности и описана в уголовном законе. Террористический акт с объективной стороны выражается альтернативно в двух формах:

1) в совершении взрыва, поджога или иных действий, устрашающих население и создающих опасность гибели человека, причинения значительного имущественного ущерба либо наступления иных тяжких последствий;

2) в угрозе совершения указанных действий.

\section{Первая форма террористического акта}

Согласно ст. 205 УК РФ первая форма террористического акта совершается только путем действия. Статья 3 Федерального закона от 6 марта 2006 г. № 35-Ф3 «О противодействии терроризму»² (далее - ФЗ «О противодействии терроризму») также указывает только на действие. В литературе

\footnotetext{
1 Заметим, что понятие «террористический акт» впервые было введено в российское законодательство в ст. 64 УК РСФСР 1922 г. (См.: Мусаелян М.Ф. Историко-правовое развитие уголовного законодательства об ответственности за терроризм в России в ХX в. // История государства и права. 2009. № 14. С. 39).

${ }^{2}$ СЗ РФ. 2006. № 11. Ст. 1146; 2006. № 31. Ст. 3452.
}

существует мнение о возможности осуществления террористической акции также и путем бездействия (например, посредством невыполнения обязанностей по отключению определенных производственных или технологических процессов в энергетике, на транспорте и т. п.) $)^{3}$ Хотя такой вывод не вытекает из закона и требует дополнительной аргументации, на наш взгляд, исключать возможность подобного проявления террористических действий с учетом их многообразия не следует.

Взрыв, поджог и иные действия - способы совершения террористического акта, которые в законе исчерпывающе не определены.

Анализ судебной практики показывает, что подавляющее большинство террористических актов совершается путем взрывов (нередко в общественных местах). Под взрывом понимается совокупность быстропротекающих процессов разной природы, определяющих мгновенное освобождение большого количества энергии в ограниченном объеме за короткий промежуток времени и рассеяние (распростра-

\footnotetext{
${ }^{3}$ См.: Мальцев В.В. Терроризм: проблема уголовно-правового урегулирования // Государство и право. 1998. № 8. С. 104; Комарова М.А. Терроризм в уголовном праве России. Дисс. ... канд. юрид. наук. М., 2003. С. 81-82; Феоктистов М.В. Ответственность за терроризм и проблемы совершенствования российского уголовного законодательства / Терроризм в России и проблемы системного реагирования / Под ред. А.И. Долговой. М., Российская криминологическая ассоциация, 2004. С. 147.
} 


\section{Национальная безопасность $3(26) \cdot 2013$}

нение) этой энергии в окружающем пространстве 4 . Взрыв осуществляется чаще всего за счет освобождения химической энергии взрывчатых веществ. Взрыв приводит к образованию сильно нагретого газа (плазмы) с очень высоким давлением, который при расширении оказывает механическое воздействие (давление, разрушение) на окружающие тела' Результатом взрыва обычно является разрушение, повреждение чего-нибудь.

По своей природе различают физические, электрические, ядерные (атомные), нейтронные и химические взрывы ${ }^{6}$. Исходя из воздействия взрыва на окружающую среду и возникших при этом разрушений, различают пять категорий взрывов: незначительной силы (менее 50 г взрывчатых веществ в тротиловом эквиваленте); слабые (от 50 до 1000 г); средние (от 1 до 10 кг); сильные (от 10 до 100 кг); очень сильные (более 100 кг)

Заметим, что проведение экспертизы средств совершения взрыва (взрывчатых веществ, устройств) - основание правомерности квалификации по ст. 205 УК РФ.

Судебная коллегия по уголовным делам Верховного Суда РФ отменила приговор Краснодарского краевого суда в части осуждения виновных по ч. 1 ст. 30 УК РФ, п. «а» ч. 2 ст. 205 УК РФ, обратив внимание на то, что по делу Х. и др. не была проведена экспертами-криминалистами и взрывотехниками экспертиза в отношении предметов, обнаруженных в автомашине X. ${ }^{8}$

Поджог - это любое действие, преднамеренно направленное на вызов пожара и приводящее какойлибо объект материального мира к повреждению (уничтожению) в результате использования реакции (неконтролируемого) горения. Поджог имеет в своей первооснове пожар, то есть неконтролируемое горение, причиняющее материальный ущерб, вред жизни и здоровью граждан, интересам общества и государства9 ${ }^{9}$ Отличие поджога от других видов пожаров в

\footnotetext{
${ }^{4}$ См.: Моторный И.Д. Криминалистическая взрывотехника: новое учение в криминалистике. М., Изд. Шумилова И.И., 2000. С. 26; Белкин Р.С. Криминалистическая энциклопедия. М., Мегатрон, 2000. С. 32.

${ }^{5}$ См.: Белкин Р.С. Указ. соч. С. 32.

${ }^{6}$ См.: Беляков А.А. Криминалистическое взрывоведение: проблемы теории и практики. Красноярск, Универс, 2003. С. 17.

${ }^{7}$ См.: Моторный И.Д. Указ. соч. С. 27.

8 См.: Определение Судебной коллегии по уголовным делам Верховного Суда РФ от 5 марта 2003 г. № 18кп 003-14.

${ }^{9}$ См.: ст. 1 Федерального закона от 21 декабря 1994 г. № 69-Ф3 «О пожарной безопасности» // СЗ РФ. 1994. № 35. Ст. 3649.
}

том, что он возникает в результате умышленных действий путем создания необходимых условий возникновения горения ${ }^{10}$.

Под иными действиями следует понимать различные по характеру общеопасные действия, способные аналогично взрыву или поджогу причинить равнозначные последствия: разрушение водозащитных плотин; затопление; обвалы; камнепады; радиоактивное, химическое, бактериологическое или иное заражение местности, земель, воды или запасов продовольствия; вывод из строя объектов жизнеобеспечения; нарушение технологических либо производственных процессов; распространение отравляющих веществ, эпидемий и эпизоотий; устройство аварий, крушений на транспорте; блокирование транспорта; порча сигнальных сооружений или средств связи на железнодорожном, речном или воздушном транспорте и т.п.

Все действия при совершении террористического акта должны быть устрашающими население и создавать опасность наступления указанных в законе последствий: гибели человека, причинения значительного имущественного ущерба либо наступления иных тяжких последствий.

Устрашение населения - это создание атмосферы общественного беспокойства, когда основной психологической доминантой становятся страх, паника, неуверенность граждан в безопасности своей жизни и здоровья, в защищенности прав и свобод, недоверие к органам власти и правоохранительным органам со стороны неопределенного круга лиц, а также состояние безысходности и неуверенности в будущем.

Полагаем, что устрашение населения - это сущностная характеристика действий при террористическом акте, основное свойство деяния в целом, а не признак субъективной стороны (цель), как было в предыдущей редакции ст. 205 УК Р $\Phi^{11}$. Мы согласны с В.С. Комиссаровым в том, что «устрашение населения не может быть целью террористического акта, а является имманентно присущим ему внутренним свойством,

\footnotetext{
${ }^{10}$ См.: Антонов О.Ю. Криминалистическая характеристика преступлений, сопряженных с пожарами / Труды Академии управления: Правовые и криминалистические проблемы раскрытия и расследования преступлений. М., Академия управления МВД России, 1998. С. 140.

11 Заметим, что устрашение населения является обязательным элементом (признаком) большинства международно-правовых определений терроризма.
} 
отражающим его сущность» $»^{12}$. И.Л. Трунов также полагает, что создание атмосферы страха - это суть терроризма (а не цель), с помощью которой террористы стремятся к достижению своих целей $^{13}$. На наш взгляд, прав А. Кибальник в том, что «цель устрашения неопределенного круга лиц расплывчата» и ее трудно доказать на практике, а введение устрашения населения в качестве объективного признака позволит более четко определить критерии квалификации содеянного по ст. 205 УК РФ ${ }^{14}$.

Если лицо на почве личных неприязненных отношений действовало для устрашения конкретного лица (например, бизнес-конкурента) и взорвало в общественном месте его автомашину, деяние нужно квалифицировать как умышленное уничтожение чужого имущества общеопасным способом (ч. 2 ст. 167 УК РФ). Однако, если лицо, взорвав в общественном месте автомашину конкретного лица, желало устрашить население региона (или какой-либо группы граждан) для принуждения третьей стороны (органов власти) к принятию (или не принятию) нужного ему решения, деяние при наличии всех необходимых признаков следует квалифицировать по ст. 205 УК РФ.

Опасность - это способность причинить какойлибо вред, несчастье; возможность чего-либо опасного, какого-нибудь несчастья, вреда ${ }^{15}$.

В науке уголовного права под опасностью понимается определенное состояние объекта в результате общественно опасных изменений в нем, произведенных преступным действием субъекта, а под созданием опасности - опасность (возможность) наступления вредных последствий, что проявляется в качественно новом состоянии, наступившем в реальной действительности, при котором появились реальные, вполне конкретные условия, силы, способ-

\footnotetext{
${ }^{12}$ См.: Терроризм. Правовые аспекты противодействия: нормативные и международные правовые акты с комментариями, научные статьи / Под ред. И.Л. Трунова, Ю.С. Горбунова. М., Эксмо, 2007. С. 212.

${ }^{13}$ См.: Трунов И.Л. Совершенствование правовых основ противодействия терроризму / ФСБ России. Правовое регулирование деятельности федеральной службы безопасности по обеспечению национальной безопасности Российской Федерации / Под ред. В.Н. Ушакова, И.Л. Трунова. М., Эксмо, 2006. С. 383.

${ }^{14}$ См.: Кибальник А. Оценка «антитеррористических» новелл уголовного закона // Уголовное право. 2006. № 5. С. 49.

${ }^{15}$ См.: Кабакович Г.А., Фильков С.М. Проблемы национальной безопасности и контроль над вооружениями. М., МГИМО(У) МИД России, 2007. С. 10.
}

ные причинить ущерб объекту ${ }^{16}$. Некоторые авторы под опасностью понимают потенциальную угрозу причинения ущерба тем или иным социальным (национальным) интересам ${ }^{17}$. Мы согласны с этим, так как потенциально любая опасность под воздействием определенных факторов и условий может трансформироваться в конкретную угрозу ${ }^{18}$.

Вышеуказанные действия, устрашающие население, должны обязательно создавать реальную опасность наступления тяжких последствий альтернативно: а) гибели человека; б) причинения значительного имущественного ущерба; в) наступления иных тяжких последствий. Если при террористическом акте не создается реальная опасность для жизни людей, собственности и т. П., ответственность по ст. 205 УК РФ исключается.

Реальность опасности наступления указанных тяжких последствий следует оценивать на основе имеющихся данных о времени, обстановке, месте, способе и других обстоятельствах совершения террористического акта (сила взрыва, масштаб поджога и т. п.). Необходимо также учитывать информацию о личности преступника, его профессиональной подготовке, наличии у него оружия, взрывчатых веществ и т. п., а также о влиянии на механизм преступного посягательства других привходящих, нередко случайных обстоятельств (скопление людей, техники, транспорта и т. п.) $)^{19}$.

Для квалификации взрыва, поджога или иных действий, устрашающих население, как террористический акт, достаточно только создания ими реальной опасности наступления названных последствий (фактическое наступление последствий необязательно).

По мнению некоторых авторов, в ст. 205 УК РФ следует предусмотреть реальное наступление по-

\footnotetext{
${ }^{16}$ См.: Кузнецьова Н.Ф. Значение преступных последствий для уголовной ответственности. М., Юридическая литература, 1958. С. 24-25.

${ }^{17}$ См.: Мохов Е.А. ФСБ: борьба с организованной преступностью. М., Вузовская книга, 2006. С. 31.

${ }^{18}$ См.: Гыскэ А.В. Современная российская преступность и проблемы безопасности общества (политический анализ). M., 2000. C. 32.

${ }^{19}$ См.: Дерюгина Ю.Н. Терроризм: уголовно-правовой и криминологический аспекты. Дисс. ... канд. юрид. наук. М., 2001. C. 123; Дьяков С.В. Государственные преступления (против основ конституционного строя и безопасности государства) и государственная преступность. М., Норма, 1999. С. 55.
} 


\section{Национальная безопасность 3(26) • 2013}

следствий, а не опасность их наступления ${ }^{20}$, по мнению других - взрыв и поджог создают не опасность, а влекут реальные человеческие жертвы, уничтожение или повреждение материальных ценностей, а потому объективная сторона в ч. 1 ст. 205 УК РФ сконструирована неточно ${ }^{21}$. Конструирование объективной стороны террористического акта как материального состава, на наш взгляд, не будет отвечать характеру и степени общественной опасности деяния и особенностям борьбы с ним.

Опасность наступления тяжких последствий, два из которых названы в законе, - это, во-первых, опасность гибели человека, что означает опасность наступления смерти хотя бы одного человека. Необходимо отметить, что ранее ч. 1 ст. 205 УК РФ говорила об «опасности гибели людей», в связи с чем, в литературе справедливо отмечалось о целесообразности указания на возможность гибели человека ${ }^{22}$, что и было учтено законодателем. Заметим также, что, описывая объективную сторону террористического акта, УК Украины (ч. 1 ст. 258) и УК Грузии (ч. 1 ст. 323) также указывают на действия, которые создают опасность для жизни человека (а не людей).

Другой вид возможных тяжких последствий опасность причинения значительного имущественного ущерба. Она зависит от возможной стоимости и значимости уничтоженных или поврежденных материальных ценностей и размера предполагаемого ущерба, вызванного необходимостью восстановительных работ, перерывом деятельности предприятий. Значительный имущественный ущерб - понятие оценочное и определяется судом с учетом обстоятельств конкретного дела (например, материального положения потерпевшего, рода его деятельности, значимости этого имущества для него, финансового состояния организации - собственника имущества). При оценке фактически причиненного материального ущерба, считаем допустимым исходить также из примечания 2 к ст. 158 УК РФ.

\footnotetext{
${ }^{20}$ См.: Матвеева А.А. Противодействие терроризму: изменения в уголовном законодательстве РФ и конституционные права граждан / Конституционные основы уголовного права. Материалы I Всероссийского конгресса по уголовному праву / Отв. ред. В.С. Комиссаров. М., Проспект, 2006. С. 591.

${ }^{21}$ См.: Аксенов О. В чьих интересах совершается теракт? // Российская юстиция. 2001. № 1. С. 59.

${ }^{22}$ См.: Дерюгина Ю.Н. Указ. соч. С. 123; Сопов Д.В. Некоторые аспекты квалификации актов терроризма / Пять лет действия УК РФ: итоги и перспективы. Материалы конференции (МГУ, 30-31 мая 2002 г.). М., ЛексЭст, 2003. С. 406.
}

В литературе высказано мнение о том, что применительно к ст. 205 УК РФ понятие значительного имущественного ущерба не связано с определенной стоимостью. Определяющим, как считает В.И. Радченко, является установление, насколько уничтожение и повреждение этого имущества либо угроза такого уничтожения или повреждения способны повлиять на сознание населения или на действия органов власти. Это, по мнению автора, возможно и при сравнительно ограниченной ценности имущества и зависит от того, насколько устрашающим является способ уничтожения. В подтверждение своей точки зрения автор приводит следующий пример: взрыв в общественном месте автомобиля с целью добиться от властей определенных действий должен квалифицироваться по ст. 205 УК РФ, в то же время сожжение валютных ценностей, соответствующих стоимости этого автомобиля, с той же целью при определенных обстоятельствах - по ст. 167 УК РФ ${ }^{23}$.

Полагаем, что указанную позицию нельзя однозначно воспринять. Нисколько не ставя под сомнение то, что применительно к ст. 205 УК РФ понятие значительного имущественного ущерба обусловлено определенным объемом и стоимостью причиненного (возможного) ущерба, целесообразно обратить внимание на определенную взаимосвязь устрашающего способа уничтожения или повреждения имущества с ценностью данного имущества. Чем «ценнее» будет это имущество, тем способ его уничтожения или повреждения будет более изобретательным и устрашающим. Исходя из сказанного, полагаем, что уничтожение или повреждение более ценного имущества либо угроза его уничтожения или повреждения больше способно повлиять на сознание населения или на действия органов власти, чем имущества менее ценного. Например, больший общественный резонанс и «реакцию» властей вызвало бы уничтожение вследствие террористического акта самолета, чем автомашины, многоэтажного здания (вспомним, здания Международного Торгового Центра в США), чем дачного домика.

По мнению М.А. Комаровой, понятие «значительный имущественный ущерб» следует исключить, так как оно является оценочным, имеет другое значение, чем в преступлениях против собственности, и охватывается понятием «иные тяжкие последствия» ${ }^{24}$.

\footnotetext{
${ }^{23}$ См.: Комментарий к Уголовному кодексу Российской Федерации / Отв. ред. В.М. Лебедев. М., Юрайт, 2006. С. 523.

${ }^{24}$ См.: Комарова М.А. Указ. соч. С. 87-88.
} 
Мы не согласны с этим, так как автор не учел наиболее частую возможность и опасность наступления именно такого последствия, как «значительный имущественный ущерб» (наряду с опасностью гибели человека). Заметим также, что о возможности (опасности) наступления последствия, аналогичного значительному имущественному ущербу, при совершении терроризма говорят также некоторые УК стран СНГ, например, ч. 1 ст. 289 УК Республики Беларусь, ч. (1) ст. 278 УК Республики Молдова ${ }^{25}$ указывают на создание опасности причинения ущерба в крупном размере, а ч. 1 ст. 323 УК Грузии - создание угрозы причинения значительного имущественного вреда.

Под опасностью наступления иных тяжких последствий понимается опасность причинения не любых по характеру и размеру последствий, а сопоставимых, равнопорядковых гибели человека или значительному имущественному ущербу. Понятие «иные тяжкие последствия» закон не раскрывает. Этот оценочный признак должен толковаться правоприменителем в каждом конкретном случае, исходя из всех обстоятельств дела. На наш взгляд, с учетом судебной практики, можно говорить о таких тяжких последствиях, как причинение двум или более лицам средней тяжести вреда здоровью или тяжкого вреда здоровью одному лицу; остановка работы транспорта, аэропорта, железных дорог; нарушение работ связи; дезорганизация нормальной деятельности органов власти или местного самоуправления, организаций, предприятий и учреждений; причинение значительного материального ущерба; уничтожение памятников истории и культуры; вывод из строя систем энерго-, водо-, теплоснабжения или других систем жизнеобеспечения; порождение массовой паники, потока беженцев; массовые отравления; распространение эпидемий и эпизоотий; химическое или радиоактивное заражение окружающей среды; наступление экологической катастрофы; иная дестабилизация обстановки и т. п. ${ }^{26}$

${ }^{25}$ См.: Уголовный кодекс Республики Молдова. Кишинев, Молдпресс, 2002.

26 Заметим, что первоначальная редакция ст. 3 ФЗ «О противодействии терроризму», в отличие от ч. 1 ст. 205 УК РФ, указывала еще на один признак объективной стороны террористического акта - создание опасности наступления экологической катастрофы. Хотя террористический акт способен привести к такому наиболее опасному для общества последствию, мы согласны с тем, что Федеральным законом от 27 июля 2006 г. № 153-Ф3 «О внесении изменений в отдельные законодательные акты Российской Федерации в связи с принятием Федерального закона «О ратификации Конвенции Совета Европы
Полагаем, что опасность любого вреда здоровью неправомерно считать «иным тяжким последствием», так как это излишне расширит указанное понятие. Поэтому справедливо мнение В.С. Комиссарова о том, что реальное причинение легкого вреда здоровью, незначительного имущественного ущерба и иных подобных последствий нужно рассматривать как элемент «создания опасности гибели людей, причинения значительного имущественного ущерба либо наступления иных общественно опасных последствий» ${ }^{27}$. Указанный подход подтверждается и судебной практикой ${ }^{28}$.

Мы считаем правильным указание в ч. 1 ст. 205 УК РФ на признак опасности наступления «иных тяжких последствий», так как вряд ли возможно в рамках ст. 205 УК РФ исчерпывающе охватить опасность наступления всех разнообразных последствий террористического акта ${ }^{29}$.

При совершении террористического акта создание опасности наступления тяжких последствий может иметь место, как альтернативно к каждому из вышеуказанных последствий, так и одновременно ко всем ${ }^{30}$.

С точки зрения законодательной конструкции террористический акт - преступление с формальным составом $^{31}$ и считается оконченным с момента совершения взрыва, поджога или иных действий, когда они подействовали устрашающе на население и создали реальную опасность гибели человека, причинения значительного имущественного ущерба либо наступления иных тяжких последствий. Следовательно,

о предупреждении терроризма» и Федерального закона «О противодействии терроризму» (СЗ РФ. 2006. № 31. Ст. 3452) был исключен данный признак, так как он охватывается «иными тяжкими последствиями».

${ }^{27}$ См.: Курс уголовного права. Особенная часть. Т. 4 / Под ред. Г.Н. Борзенкова, В.С. Комиссарова. М., Зерцало-М, 2002. C. 213 .

${ }^{28}$ См.: Дело М. и М.-ов // Архив Ставропольского краевого суда. Дело № 2-13/02.

29 Заметим, что об опасности наступления «иных тяжких последствий» говорила также ч. 1 ст. $213^{3}$ УК РСФСР 1960 г.

${ }^{30}$ См.: Дело М. // Архив Ставропольского краевого суда. Дело № 2-18/03.

${ }^{31}$ См.: Киреев М.П. Проблемы борьбы органов внутренних дел с актами терроризма / Терроризм: современные аспекты / Отв. за выпуск Г.В. Самойлов. М., Академия управления МВД России, 1999. С. 7; Егоров В.С. Уголовная ответственность за преступления против общественной безопасности и общественного порядка. М., Московский психолого-социальный институт, НПО «МОДЭК», 2000. С. 8. 
для оконченного состава террористического акта не требуется фактического наступления общественно опасных последствий (они лежат за пределами основного состава). В случае их наступления при наличии умысла содеянное может быть квалифицировано по п. «в» ч. 2 (если был причинен значительный имущественный ущерб либо наступили иные тяжкие последствия) или п. «б» ч. 3 (если была причинена смерть человеку) ст. 205 УК РФ ${ }^{32}$. Если последствия в виде смерти человека причинены по неосторожности, содеянное следует квалифицировать по п. «б» ч. 2 ст. 205 УК РФ.

\section{Вторая форма террористического акта}

На практике трудности возникают при квалификации второй формы террористического акта - угрозы совершения взрыва, поджога или иных действий, устрашающих население и создающих опасность гибели человека, причинения значительного имущественного ущерба либо наступления иных тяжких последствий. Это нередко обусловлено сущностью понятия «угроза» и его неоднозначным толкованием в науке уголовного права ${ }^{33}$.

Под угрозой совершения террористического акта следует понимать психическое воздействие на людей, органы государственной власти и местного самоуправления, международные организации, их должностных лиц, объективно проявляющееся вовне в форме высказывания намерения в определенных целях учинить взрыв, поджог или иные устрашающие действия и создающие опасность гибели человека, причинения значительного имущественного ущерба либо наступления иных тяжких последствий.

Угроза совершения террористического акта, как и реальное его совершение, способна породить страх, панику, дестабилизировать обстановку, вызвать беспорядки, дезорганизовать работу транспорта, предприятий, учреждений, организаций, вынудить правоохранительные органы проводить сложные

\footnotetext{
32 Заметим, что ранее такие случаи не охватывались ст. 205 УК РФ и нередко квалифицировались по совокупности преступлений, предусмотренных ст. 205 и ст. 167, ч. 3 ст. 205 и соответствующими пунктами ч. 2 ст. 105 УК РФ.

${ }^{33}$ Более подробно о содержании угрозы с этимологической, законодательной и уголовно-правовой позиций см.: Mycaeлян М.Ф. Квалификация угрозы террористического акта в судебной практике / Комментарий судебной практики. Вып. 14 / Под ред. К.Б. Ярошенко. М., Юридическая литература, 2008. С. 228-230.
}

предупредительно-профилактические мероприятия. Угроза террористического акта может выражаться только в совершении указанных в ч. 1 ст. 205 УК РФ действий. Угроза совершения иных действий не является террористическим актом, но может образовать состав другого преступления (например, ст. 119, 296, 318 УК РФ). Существует мнение, что угрожать можно также бездействием ${ }^{34}$.

Обязательным для привлечения лица к ответственности за угрозу террористического акта является реальность высказанной угрозы. Угроза террористического акта должна быть действительной и реальной, то есть включать в себя не одно только высказанное намерение учинить террористический акт, но и совершение действий, свидетельствующих о серьезности и реальности такого намерения и направленных на реализацию высказанной угрозы (либо должны иметься все основания полагать, что лицо в состоянии осуществить такую угрозу без предварительной подготовки). Если угроза не оказалась реальной и ни в чем, кроме высказывания намерения, не выражалась, хотя и была направлена на устрашение населения и сопровождалась определенными требованиями, она не может рассматриваться как террористический акт. Одного лишь факта обнаружения умысла недостаточно ${ }^{35}$. Таким образом, от угрозы-преступления (то есть психического воздействия на лицо с целью изменения его поведения в интересах угрожающего) следует отличать обнаружение умысла (то есть высказывание намерения совершить преступление) ${ }^{36}$. Именно реальность намерения, объективизировавшаяся в конкретных действиях, отличает угрозу от высказывания в форме обнаружения умысла и придает ей уголовно-правовой характер ${ }^{37}$.

\footnotetext{
${ }^{34}$ См.: Емельянов В. Разграничение терроризма и посягательств с элементами терроризирования // Российская юстиция. 2001. № 4. С. 50.

${ }^{35}$ См.: Комиссаров В.С. Терроризм, бандитизм, захват заложника и другие тяжкие преступления против безопасности общества. По новому УК РФ. М., Кросна-Лекс, 1997. С. 67; Емельянов В.П. Терроризм и преступления с признаками терроризирования: уголовно-правовое исследование. СПб., Юридический центр Пресс, 2002. С. 201-202; Дерюгина Ю.Н. Указ. соч. С. 128; Беляков А.А., Тишин Д.В. Виртуальные взрывы. М., Юрлитинформ, 2004. С. 13.

${ }^{36}$ См.: Галахова А.В. Уголовно-правовая защита личности и профессиональной деятельности судебных приставов. М., РПА МЮ РФ, 2004. С. 15.

${ }^{37}$ См.: Курс уголовного права. Особенная часть. Т. 4 / Под ред. Г.Н. Борзенкова, В.С. Комиссарова. С. 212.
} 
Элемент реальности угрозы в составе террористического акта должен включать в себя одновременно субъективный и объективный факторы ${ }^{38}$. Это означает, что в случае угрозы террористического акта угроза, исходящая от лица, готовящего или подготовившего террористический акт, должна быть реальной и вызывать у населения и органов власти обоснованное опасение ее осуществления, которые должны воспринимать угрозу как желание лица действительно реализовать ее и создать реальную опасность для жизни или здоровья людей, а не как пустую шутку (субъективный фактор). Таковой, например, является угроза, подкрепленная совершением действий, свидетельствующих о серьезности и реальности такого намерения и направленных на реализацию высказанной угрозы (например, приобретение взрывчатых, биологически опасных, радиоактивных веществ; демонстрация готового к применению взрывного устройства, огнестрельного оружия или горящего факела; совершение «предупреждающих» взрывов и поджогов, стрельба поверх головы и т. п.) (объективный фактор). Таким образом, при оценке реальности угрозы необходимо учитывать как объективные, так и субъективные моменты (факторы). Поэтому нельзя согласиться с мнением О.Л. Дубовик о том, что для наступления ответственности по ст. 205 УК РФ «не имеет значения, насколько реальным было осуществление угрозы» ${ }^{39}$. Если не будут установлены объективные основания для осуществления угрозы, ответственность по ст. 205 УК РФ исключается ${ }^{40}$.

Частный предприниматель 3. с целью повлиять на принятое Государственной налоговой инспекцией решение и уклониться от уплаты долгов изготовил письмо, предназначенное заместителю начальника налоговой инспекции Ч. В этом письме он указал, что если налоговая инспекция примет меры по взысканию с него долга, он убьет свою жену, детей, произведет массовое отравление сотрудников налоговой инспекции и жителей близлежащих домов отравля-

\footnotetext{
${ }^{38}$ Реальность угрозы является одним из наиболее дискуссионных вопросов, возникающих при квалификации угрозы террористического акта. Более подробно об этом см.: $M y c a-$ елян М.Ф. Квалификация угрозы террористического акта в судебной практике / Комментарий судебной практики. Вып. 14 / Под ред. К.Б. Ярошенко. С. 230-236.

${ }^{39}$ См.: Учебно-практический комментарий к Уголовному кодексу Российской Федерации / Под общ. ред. А.Э. Жалинского. М., Эксмо, 2005. С. 618.

${ }^{40}$ См.: Комиссаров В.С. Указ. соч. С. 67.
}

ющим веществом - фосгеном, которое помещено в канализационную сеть здания инспекции. 3. передал данное письмо сотруднику налоговой инспекции. После получения такого письма сотрудники налоговой инспекции, которые имели реальные основания опасаться осуществления указанных в нем угроз, обратились в УФСБ РФ.

Органы предварительного расследования квалифицировали действия 3. по ч. 1 ст. 205 УК РФ как угрозу совершения террористического акта путем массового отравления. Однако суд переквалифицировал действия 3. на ст. 119 УК РФ, указав, что «под угрозой совершения террористического акта понимается лишь угроза, подкрепленная совершением действий, свидетельствующих о реальности намерения», а 3. не совершал и не имел возможности совершить какие-то действия, направленные на реализацию высказанной в заявлении угрозы и свидетельствующих о его реальности. Квалификацию деяния по ст. 119 УК РФ суд обосновал также тем, что 3. угрожал убийством, по крайней мере, нескольким лицам, осведомленным о содержании его заявления, которые имели реальные основания опасаться осуществления этой угрозы. Верховный Суд РФ такую квалификацию оставил в силе ${ }^{41}$.

Аналогичным образом решается вопрос о реальности угрозы террористического акта и в определениях Судебной коллегии по уголовным делам Верховного Суда РФ по делу К. и по делу Ш. ${ }^{42}$

Реальность угрозы устанавливается с учетом конкретных обстоятельств преступления (время, место, обстановка, способ и т. п.), влияния на механизм преступного деяния других привходящих, нередко случайных обстоятельств (например, скопление людей, техники, транспортных средств и т. п.). При оценке реальности угрозы совершения террористического акта следует также учитывать то, что восприятие угрозы сугубо субъективно и на этот процесс может оказывать существенное влияние такой фактор, как личность угрожающего (его криминальное прошлое, положение в криминальном сообще-

\footnotetext{
${ }^{41}$ См.: Определение Судебной коллегии по уголовным делам Курганского областного суда от 5 января 2000 г.; Определение Судебной коллегии по уголовным делам Верховного Суда РФ от 9 марта 2000 г. № 82-000-19.

${ }^{42}$ См.: Определение Судебной коллегии по уголовным делам Верховного Суда РФ от 11 апреля 2000 г. № 82-000-26; Определение Судебной коллегии по уголовным делам Верховного Суда РФ от 18 августа 1999 г. № 82-099-23.
} 


\section{Национальная безопасность $3(26) \cdot 2013$}

стве, связи с бандформированиями, авторитет среди террористов и т. п.) $)^{43}$. Исходя из этого, в некоторых случаях для квалификации угрозы террористического акта как оконченного преступления, возможно, будет достаточно наличия только «субъективного фактора». Так, угрозы совершить террористические акты путем взрывов, использования радиоактивных или биологически опасных веществ, высказанные в свое время чеченскими террористами Ш. Басаевым и C. Радуевым, можно квалифицировать как оконченный состав угрозы террористического акта. Учитывая одиозную личность данных террористов, совершивших не один террористический акт с сотнями жертв, а также их известность и «авторитет» среди террористов, высказанные ими угрозы вполне могли вызвать у населения и властей реальные опасения их осуществления, даже при отсутствии попыток выполнить эти угрозы.

Таким образом, элемент реальности угрозы при террористическом акте является необходимым признаком угрозы. Исходя из этого, мы полагаем, что характеристика угрозы террористического акта требует указания на наличие оснований опасаться осуществления угрозы (как это сделано, например, в ст. 119 УК РФ).

Любая угроза террористического акта должна включать в себя как озвучивание характера общественно опасных действий, совершением которых угрожают, так и мотивов и целей их совершения (обычно требование совершить те или иные действия). Для квалификации угрозы террористического акта и ее оценки как реальной не имеет значения, к кому она обращена (к общественности, к государственным учреждениям и т. п.), является открытой или анонимной, а также в какой форме она распространяется (способы передачи): устно, письменно, с помощью средств массовой информации, листовок, телефона и т. п.

По нашему мнению, законодатель в ч. 1 ст. 205 УК РФ, уравняв по степени опасности реальное совершение взрыва, поджога или иных действий и угрозу их совершения, не учел объективные различия в степени опасности действий и угрозы их совершения. Поэтому высказывания о выделении угрозы совершения террористического акта в ${ }^{43}$ См.: Антонян Ю.М. Терроризм. Криминологическое и уго-
ловно-правовое исследование. М., Щит-М, 2001. С. 280. самостоятельную норму УК РФ целесообразны ${ }^{44}$, однако не в отдельную часть ст. 205 УК РФ $\Phi^{45}$.

В УК большинства стран СНГ (за исключением ч. 1 ст. 323 УК Грузии) также предусмотрена ответственность за угрозу терроризма. В УК Республики Беларусь ответственность за терроризм и угрозу совершением акта терроризма установлена в самостоятельных статьях (ст.ст. 289 и 290 соответственно). Учитывая различную степень общественной опасности данных форм террористического акта, считаем возможным дополнить УК РФ ст. $205^{3}$ «Угроза совершением террористического акта», включив в диспозицию нормы указание на признак реальности угрозы в такой редакции - «если имелись основания опасаться осуществления этой угрозы». Редакция статьи могла бы быть такой:

«1. Угроза совершения террористического акта, если имелись основания опасаться осуществления этой угрозы, совершенная с указанной в ст. 205 УК целью, -

наказывается...

2. Те же действия, совершенные:

а) группой лиц по предварительному сговору;

б) причинившие значительный имущественный ущерб или иные тяжкие последствия, -

наказываются...».

Это предложение предполагает и изменение редакции ч. 1 ст. 205 УК РФ: из нее следует исключить слова «а также угроза совершения указанных действий в тех же целях».

Угроза независимо от ее форм признается оконченным преступлением с момента ее объективизации (выражения), то есть доведения до широкого или узкого круга лиц, если она вызвала реальные опасения ее осуществления. При этом для квалификации не имеет значения, желал или не желал субъект фактически привести угрозу в исполнение.

Мы не согласны с мнением о том, что по законодательной конструкции террористический акт - формально-материальный состав преступления (при совершении взрыва, поджога или иных действий

\footnotetext{
${ }^{44}$ См.: Попов В.И. Актуальные проблемы борьбы с наиболее опасными проявлениями организованной преступности. М., СГУ, 2004. С. 209-210; Мальцев В.В. Указ. соч. С. 104-107; Милюков С.Ф. Российское уголовное законодательство. Опыт критического анализа. СПб., Знание, 2000. С. 244-246.

${ }^{45}$ См.: Сопов Д.В. Уголовная ответственность за терроризм: проблемы квалификации. Дисс. ... канд. юрид. наук. М., 2004. C. 85 .
} 
- материальный, а при угрозе совершения указанных действий - формальный $)^{46}$.

Террористический акт в форме угрозы следует отграничивать от заведомо ложного сообщения об акте терроризма (ст. 207 УК РФ) - по реальности угрозы и направленности умысла. В отличие от угрозы террористического акта, заведомо ложное сообщение об акте терроризма является лишь высказанным намерением совершить террористический акт и не преследует цель воздействия на принятие решения органами власти или международными организациями ${ }^{47}$.

\section{Библиография:}

1. Мусаелян М.Ф. Историко-правовое развитие уголовного законодательства об ответственности за терроризм в России в XX в. // История государства и права. 2009. № 14.

2. Федеральный закон от 6 марта 2006 г. № 35-Ф3 «О противодействии терроризму» // С3 РФ. 2006. № 11. Ст. 1146; 2006. № 31. Ст. 3452.

3. Мальцев В.В. Терроризм: проблема уголовноправового урегулирования // Государство и право. 1998. № 8 .

4. Комарова М.А. Терроризм в уголовном праве России. Дисс. ... канд. юрид. наук. М., 2003.

5. Феоктистов М.В. Ответственность за терроризм и проблемы совершенствования российского уголовного законодательства / Терроризм в России и проблемы системного реагирования / Под ред. А.И. Долговой. М., Российская криминологическая ассоциация, 2004.

6. Моторный И.Д. Криминалистическая взрывотехника: новое учение в криминалистике. М., Изд. Шумилова И.И., 2000.

7. Белкин Р.С. Криминалистическая энциклопедия. М., Мегатрон, 2000

8. Беляков А.А. Криминалистическое взрывоведение: проблемы теории и практики. Красноярск, Универс, 2003.

\footnotetext{
${ }^{46}$ См.: Сопов Д.В. Уголовная ответственность за терроризм: проблемы квалификации. Дисс. ... канд. юрид. наук. С. 81-82; 84; Дерюгина Ю.Н. Указ. соч. С. 127; 130; 132.

47 Более подробно об этом см.: Мусаелян М.Ф. Квалификация угрозы террористического акта в судебной практике / Комментарий судебной практики. Вып. 14 / Под ред. К.Б. Ярошенко. С. 236-237.
}

9. Определение Судебной коллегии по уголовным делам Верховного Суда РФ от 5 марта 2003 г. № 18кп 003-14.

10. Федеральный закон от 21 декабря 1994 г. № 69Ф3 «О пожарной безопасности» // С3 РФ. 1994. № 35. Ст. 3649.

11. Антонов О.Ю. Криминалистическая характеристика преступлений, сопряженных с пожарами / Труды Академии управления: Правовые и криминалистические проблемы раскрытия и расследования преступлений. М., Академия управления МВД России, 1998.

12. Терроризм. Правовые аспекты противодействия: нормативные и международные правовые акты с комментариями, научные статьи / Под ред. И.Л. Трунова, Ю.С. Горбунова. М., Эксмо, 2007.

13. Трунов И.Л. Совершенствование правовых основ противодействия терроризму / ФСБ России. Правовое регулирование деятельности федеральной службы безопасности по обеспечению национальной безопасности Российской Федерации / Под ред. В.Н. Ушакова, И.Л. Трунова. М., Эксмо, 2006.

14. Кибальник А. Оценка «антитеррористических» новелл уголовного закона // Уголовное право. 2006. № 5 .

15. Кабакович Г.А., Фильков С.М. Проблемы национальной безопасности и контроль над вооружениями. М., МГИМО(У) МИД России, 2007.

16. Кузнецова Н.Ф. Значение преступных последствий для уголовной ответственности. М., Юридическая литература, 1958.

17. Мохов Е.А. ФСБ: борьба с организованной преступностью. М., Вузовская книга, 2006.

18. Гыскэ А.В. Современная российская преступность и проблемы безопасности общества (политический анализ). М., 2000.

19. Дерюгина Ю.Н. Терроризм: уголовно-правовой и криминологический аспекты. Дисс. ... канд. юрид. наук. М., 2001.

20. Дьяков С.В. Государственные преступления (против основ конституционного строя и безопасности государства) и государственная преступность. М., Норма, 1999.

21. Матвеева А.А. Противодействие терроризму: изменения в уголовном законодательстве РФ и конституционные права граждан / Конституционные основы уголовного права. Материалы I Всероссийского конгресса по уго- 
ловному праву / Отв. ред. В.С. Комиссаров. М., Проспект, 2006.

22. Аксенов О. В чьих интересах совершается теракт? // Российская юстиция. 2001. № 1.

23. Сопов Д.В. Некоторые аспекты квалификации актов терроризма / Пять лет действия УК РФ: итоги и перспективы. Материалы конференции (МГУ, 30-31 мая 2002 г.). М., ЛексЭст, 2003.

24. Комментарий к Уголовному кодексу Российской Федерации / Отв. ред. В.М. Лебедев. М., Юрайт, 2006.

25. Уголовный кодекс Республики Молдова. Кишинев, Молдпресс, 2002.

26. Федеральный закон от 27 июля 2006 г. № 153-Ф3 «О внесении изменений в отдельные законодательные акты Российской Федерации в связи с принятием Федерального закона «О ратификации Конвенции Совета Европы о предупреждении терроризма» и Федерального закона «О противодействии терроризму» // С3 РФ. 2006. № 31. Ст. 3452.

27. Курс уголовного права. Особенная часть. Т. 4 / Под ред. Г.Н. Борзенкова, В.С. Комиссарова. М., Зерцало-М, 2002.

28. Дело М. и М.-ов // Архив Ставропольского краевого суда. Дело № 2-13/02.

29. Дело М. // Архив Ставропольского краевого суда. Дело № 2-18/03.

30. Киреев М.П. Проблемы борьбы органов внутренних дел с актами терроризма / Терроризм: современные аспекты / Отв. за выпуск Г.В. Самойлов. М., Академия управления МВД России, 1999.

31. Егоров В.С. Уголовная ответственность за преступления против общественной безопасности и общественного порядка. М., Московский психолого-социальный институт, НПО «МОДЭК», 2000.

32. Мусаелян М.Ф. Квалификация угрозы террористического акта в судебной практике / Комментарий судебной практики. Вып. 14 / Под ред. К.Б. Ярошенко. М., Юридическая литература, 2008.

33. Емельянов В. Разграничение терроризма и посягательств с элементами терроризирования // Российская юстиция. 2001. № 4.

34. Комиссаров В.С. Терроризм, бандитизм, захват заложника и другие тяжкие преступления против безопасности общества. По новому УК РФ. М., Кросна-Лекс, 1997.

35. Емельянов В.П. Терроризм и преступления с признаками терроризирования: уголовно-право- вое исследование. СПб., Юридический центр Пресс, 2002.

36. Беляков А.А., Тишин Д.В. Виртуальные взрывы. М., Юрлитинформ, 2004.

37. Галахова А.В. Уголовно-правовая защита личности и профессиональной деятельности судебных приставов. М., РПА МЮ РФ, 2004.

38. Учебно-практический комментарий к Уголовному кодексу Российской Федерации / Под общ. ред. А.Э. Жалинского. М., Эксмо, 2005.

39. Определение Судебной коллегии по уголовным делам Курганского областного суда от 5 января 2000 г.

40. Определение Судебной коллегии по уголовным делам Верховного Суда РФ от 9 марта 2000 г. № 82-000-19.

41. Определение Судебной коллегии по уголовным делам Верховного Суда РФ от 11 апреля 2000 г. № 82-000-26.

42. Определение Судебной коллегии по уголовным делам Верховного Суда РФ от 18 августа 1999 г. № 82-099-23.

43. Антонян Ю.М. Терроризм. Криминологическое и уголовно-правовое исследование. М., Щит-М, 2001.

44. Попов В.И. Актуальные проблемы борьбы с наиболее опасными проявлениями организованной преступности. М., СГУ, 2004.

45. Милюков С.Ф. Российское уголовное законодательство. Опыт критического анализа. СПб., Знание, 2000.

46. Сопов Д.В. Уголовная ответственность за терроризм: проблемы квалификации. Дисс. ... канд. юрид. наук. М., 2004.

\section{References (transliteration):}

1. Musaelyan M.F. Istoriko-pravovoe razvitie ugolovnogo zakonodatel'stva ob otvetstvennosti za terrorizm v Rossii v XX v. // Istoriya gosudarstva i prava. 2009. № 14.

2. Mal'cev V.V. Terrorizm: problema ugolovnopravovogo uregulirovaniya // Gosudarstvo i pravo. 1998. № 8.

3. Komarova M.A. Terrorizm v ugolovnom prave Rossii. Diss. ... kand. yurid. nauk. M., 2003.

4. Feoktistov M.V. Otvetstvennost' za terrorizm i problemy sovershenstvovaniya rossiyskogo ugolovnogo zakonodatel'stva / Terrorizm v Rossii i problemy 
sistemnogo reagirovaniya / Pod red. A.I. Dolgovoy. M., Rossiyskaya kriminologicheskaya associaciya, 2004.

5. Motornyy I.D. Kriminalisticheskaya vzryvotehnika: novoe uchenie v kriminalistike. M., Izd. Shumilova I.I., 2000.

6. Belkin R.S. Kriminalisticheskaya enciklopediya. M., Megatron, 2000.

7. Belyakov A.A. Kriminalisticheskoe vzryvovedenie: problemy teorii i praktiki. Krasnoyarsk, Univers, 2003.

8. Antonov O.Yu. Kriminalisticheskaya harakteristika prestupleniy, sopryazhennyh s pozharami / Trudy Akademii upravleniya: Pravovye i kriminalisticheskie problemy raskrytiya i rassledovaniya prestupleniy. M., Akademiya upravleniya MVD Rossii, 1998.

9. Trunov I.L. Sovershenstvovanie pravovyh osnov protivodeystviya terrorizmu / FSB Rossii. Pravovoe regulirovanie deyatel'nosti federal'noy sluzhby bezopasnosti po obespecheniyu nacional'noy bezopasnosti Rossiyskoy Federacii / Pod red. V.N. Ushakova, I.L. Trunova. M., Eksmo, 2006.

10. Kibal'nik A. Ocenka «antiterroristicheskih» novell ugolovnogo zakona // Ugolovnoe pravo. 2006. № 5.

11. Kabakovich G.A., Fil'kov S.M. Problemy nacional'noy bezopasnosti i kontrol' nad vooruzheniyami. M., MGIMO(U) MID Rossii, 2007.

12. Kuznecova N.F. Znachenie prestupnyh posledstviy dlya ugolovnoy otvetstvennosti. M., Yuridicheskaya literatura, 1958.

13. Mohov E.A. FSB: bor'ba s organizovannoy prestupnost'yu. M., Vuzovskaya kniga, 2006.

14. Gyske A.V. Sovremennaya rossiyskaya prestupnost' i problemy bezopasnosti obschestva (politicheskiy analiz). M., 2000.

15. Deryugina Yu.N. Terrorizm: ugolovno-pravovoy i kriminologicheskiy aspekty. Diss. ... kand. yurid. nauk. M., 2001.

16. D'yakov S.V. Gosudarstvennye prestupleniya (protiv osnov konstitucionnogo stroya i bezopasnosti gosudarstva) i gosudarstvennaya prestupnost'. M., Norma, 1999.

17. Matveeva A.A. Protivodeystvie terrorizmu: izmeneniya v ugolovnom zakonodatel'stve RF i konstitucionnye prava grazhdan / Konstitucionnye osnovy ugolovnogo prava. Materialy I Vserossiyskogo kongressa po ugolovnomu pravu / Otv. red. V.S. Komissarov. M., Prospekt, 2006.

18. Aksenov $\mathrm{O} . \mathrm{V}$ ch'ih interesah sovershaetsya terakt? // Rossiyskaya yusticiya. 2001. № 1.
19. Sopov D.V. Nekotorye aspekty kvalifikacii aktov terrorizma / Pyat' let deystviya UK RF: itogi i perspektivy. Materialy konferencii (MGU, 30-31 maya 2002 g.). M., LeksEst, 2003.

20. Kurs ugolovnogo prava. Osobennaya chast'. T. 4 / Pod red. G.N. Borzenkova, V.S. Komissarova. M., Zercalo-M, 2002.

21. Delo M. i M.-ov // Arhiv Stavropol'skogo kraevogo suda. Delo № 2-13/02.

22. Delo M. // Arhiv Stavropol'skogo kraevogo suda. Delo № 2-18/03.

23. Kireev M.P. Problemy bor'by organov vnutrennih del s aktami terrorizma / Terrorizm: sovremennye aspekty / Otv. za vypusk G.V. Samoylov. M., Akademiya upravleniya MVD Rossii, 1999.

24. Egorov V.S. Ugolovnaya otvetstvennost' za prestupleniya protiv obschestvennoy bezopasnosti i obschestvennogo poryadka. M., Moskovskiy psihologo-social'nyy institut, NPO «MODEK», 2000.

25. Musaelyan M.F. Kvalifikaciya ugrozy terroristicheskogo akta v sudebnoy praktike / Kommentariy sudebnoy praktiki. Vyp. 14 / Pod red. K.B. Yaroshenko. M., Yuridicheskaya literatura, 2008.

26. Emel'yanov V. Razgranichenie terrorizma i posyagatel'stv s elementami terrorizirovaniya // Rossiyskaya yusticiya. 2001. № 4.

27. Komissarov V.S. Terrorizm, banditizm, zahvat zalozhnika i drugie tyazhkie prestupleniya protiv bezopasnosti obschestva. Po novomu UK RF. M., Krosna-Leks, 1997.

28. Emel'yanov V.P. Terrorizm i prestupleniya s priznakami terrorizirovaniya: ugolovno-pravovoe issledovanie. SPb., Yuridicheskiy centr Press, 2002.

29. Belyakov A.A., Tishin D.V. Virtual'nye vzryvy. M., Yurlitinform, 2004.

30. Galahova A.V. Ugolovno-pravovaya zaschita lichnosti i professional'noy deyatel'nosti sudebnyh pristavov. M., RPA MYu RF, 2004.

31. Antonyan Yu.M. Terrorizm. Kriminologicheskoe i ugolovno-pravovoe issledovanie. M., Schit-M, 2001.

32. Popov V.I. Aktual'nye problemy bor'by s naibolee opasnymi proyavleniyami organizovannoy prestupnosti. M., SGU, 2004.

33. Milyukov S.F. Rossiyskoe ugolovnoe zakonodatel'stvo. Opyt kriticheskogo analiza. SPb., Znanie, 2000.

34. Sopov D.V. Ugolovnaya otvetstvennost' za terrorizm: problemy kvalifikacii. Diss. ... kand. yurid. nauk. M., 2004. 